Vol 1, No 1, Juni 2020; 83-97

ISSN : 2723-3324

Available at: e-journal.sttberitahidup.ac.id/index.php/jan/index

\title{
Tugas Pemimpin Muda Kristen Masa Kini Sebagai Gembala Menurut 1 Timotius 4
}

\author{
Santy Sahartian ${ }^{1}$, sahartiansanty@gmail.com \\ Samuel Brian Septiadi², samuel94.niditia@gmail.com
}

\begin{abstract}
The church is God's people who need guidance and leadership so that people can know God. Therefore the Church needs a leader who understands his duties as a leader. But there are still church leaders who do not understand their duties as leaders based on Bible principles. The church is less prepared for the younger generation as leaders. This we can see in the church in general does not provide opportunities for young people to develop their potential to lead. This church's disbelief in youth leadership is increasingly apparent because of the life of the Christian youth itself. Aside from not being able to be considered capable, the church is reluctant to entrust great responsibility to the youth because the lives of Christian youth are often considered far from God's word. Today's young Christian leaders are those who carry out Christian leadership duties at a relatively young age. Today's young leaders have so many weaknesses that young leaders are less accepted and respected by many people, so that Christian youths are trusted they must carry out the duties of young Christian leaders today according to 1 Timothy 4 namely young Christian leaders should remind the congregation of the word, teach the truth of the word, be an example for God's people who are led, grow in service, supervise themselves and teachings. So that the Christian Young leaders can be respected by everyone.
\end{abstract}

Keywords: Task, Young Leaders, I Timothy 4

\section{Abstrak}

Gereja merupakan umat Allah yang memerlukan pembinaan dan kepemimpinan sehingga umat dapat mengenal Allah. Maka dari itu Gereja membutuhkan sosok pemimpin yang memahami tugasnya sebagai pemimpin. Namun masih ditemukan pemimpin gereja yang kurang memahami tugasnya sebagai pemimpin berdasarkan prinsip-prinsip Alkitab. Gereja kurang mempersiapkan generasi muda sebagai pemimpin. Hal ini dapat kita lihat di dalam gereja secara umum tidak memberikan kesempatan bagi pemuda untuk mengembangkan potensinya dalam memimpin. Ketidak pecayaan gereja terhadap kepemimpinan pemuda ini semakin nyata karena kehidupan pemuda Kristen itu sendiri. Selain karena kurang di anggap mampu, gereja enggan mempercayakan tanggung jawab yang besar kepada pemuda karena kehidupan pemuda Kristen yang sering kali dianggap jauh dari firman Tuhan. Pemimpin muda Kristen masa kini adalah seorang yang menjalankan tugas kepemimpinan Kristen dalam usia yang relative muda. Pemimpin muda masa kini memiliki banyak sekali kelemahan sehingga pemimpin muda kurang diterima dan dihargai oleh orang banyak, agar

\footnotetext{
${ }^{1}$ Dosen Sekolah Tinggi Teologi Berita Hidup

${ }^{2}$ Guru Pendidikan Agama Kristen Sekolah Dasar Triwindu Surakarta
} 
pemuda kristen dipercayai maka harus menjalankan tugas pemimpin muda Kristen masa kini t menurut 1 Timotius 4 yaitu pemimpin muda kristen seharusnya mengingatkan jemaat akan firman, mengajarkan kebenaran firman, menjadi teladan bagi umat Tuhan yang dipimpin, bertumbuh dalam pelayanan, mengawasi diri dan ajaran. Sehingga pemimpin Muda Kristen dapat dihargai seiap orang.

Kata-kata kunci: Tugas, Pemimpin Muda, I Timotius 4

\section{PENDAHULUAN}

Gereja merupakan umat Allah yang memerlukan pembinaan dan kepemimpinan sehingga umat dapat mengenal Allah. Maka dari itu Gereja membutuhkan sosok pemimpin yang memahami tugasnya sebagai pemimpin. Namun masih ditemukan pemimpin gereja yang kurang memahami tugasnya sebagai pemimpin berdasarkan prinsip-prinsip Alkitab.

Seorang pemimpin membutuhkan kemampuan untuk memimpin. Kemampuan tersebut dapat diperolehnya dari potensi yang ada padanya sejak lahir dan juga dari pengalaman, belajar secara formal ataupun informal serta dari karunia memimpin yang didapat dari Tuhan. Larry S. Julian mengatakan dalam buku "God is my CEO”:

"Rancangan Tuhan tentang kepemimpinan memiliki sebuah fondasi yang kokoh dan seimbang, serta dibangun untuk bertumbuh semakin kuat di sepanjang waktu di tengah tekanan eksternal. Model kepemimpinan ini memanfaatkan waktu dan tekanan untuk menghasilkan kebijaksanaan, pertumbuhan karakter, serta memaksimalkan produktivitas". 3

Melihat pentingnya kepemimpinan dalam gereja, seharusnya gereja mempersiapkan pemimpin-pemimpin yang akan datang untuk diperlengkapi dengan ketrampilan dalam kepemimpinan dan diajarkan bagamana hidup seorang pemimpin itu. Gereja hingga saat ini kurang memperhatikan hal tentang persiapan pemimpin yang akan datang. Gereja hanya berfokus pada hal-hal yang rutin atau yang sedang dihadapi seperti halnya menentukan jadwal pelayanan, membuat program jangka pendek, pembangunan, persiapan hari-hari besar Kristen tanpa memperhitungkan kehidupan gereja yang akan datang.

Generasi muda gereja punya semangat yang tinggi dan pikiran-pikiran yang kreatif. Namun yang terjadi adalah pemuda dalam gereja kurang diperhatikan. Padahal tanpa disadari pemuda merupakan tulang punggung gereja yang menentukan masa depan gereja. Gereja kurang mempersiapkan pemuda sebagai pemimpin. Hal ini dapat kita lihat di dalam gereja secara umum tidak memberikan kesempatan bagi pemuda untuk mengembangkan

\footnotetext{
${ }^{3}$ Larry S. Julian, GOD Is My CEO (Jakarta: BIP, 2004).xxvi
} 
potensinya dalam memimpin. Gereja hanya memberikan tanggung jawab yang kecil dalam gereja. Dan sangat jarang adanya pelatihan khusus bagi pemuda untuk menjadi pemimpin.

Pekerjaan pemimpin adalah untuk membantu para remaja putra dan remaja putri belajar dan menerapkan asas-asas yang akan membantu mereka memimpin dengan cara Juruselamat4. Berikut adalah empat asas tersebut. Kepemimpinan itu sendiri tidak pernah mempersoalkan tentang usia pemimpin. Di dalam Alkitab sendiri banyak pemimpin dalam usia muda yang begitu luar biasa, seperti Daud, Yosia, Timotius. Tokoh- tokoh di atas dapat di pakai Tuhan secara luar biasa. Dengan kata lain Tuhan bisa memakai siapapun.

Seorang misionaris muda menggambarkan kepemimpinan dengan sangat sederhana. Dia berkata, "Kita harus berada di tempat yang tepat pada waktu yang tepat dalam melakukan kehendak Tuhan dan membantu orang yang membutuhkan bantuan kita. Itulah yang menjadikan kita pemimpin.” Karena jati diri mereka dan Terang Kristus yang bersinar dalam diri mereka, para remaja putra dan remaja putri yang setia dalam Gereja ini memiliki kemampuan untuk memimpin dengan cara Juruselamat dan "membantu orang lain menjadi para pengikut sejati Yesus Kristus.”

Gereja tidak dapat menaruh kepercayaan terhadap pemuda itu sendiri juga dipengaruhi beberapa faktor. Pertama, gereja melihat tugas sebagai pemimpin tidaklah mudah sehingga pemuda dianggap belum mampu menjadi seorang pemimpin. Kedua, kehidupan pemuda yang masih duniawi. Hingga saat ini keberadaan Pemuda di dalam gereja di anggap kurang mampu untuk memimpin. Pengalaman hidup yang terhitung sedikit karena usia yang muda membuat pemuda kurang dipercaya untuk memimpin sebuah organisasi yang di dalamnya juga terdapat orang-orang yang lebih tua. Fenomena yang sering kali terjadi adalah kebanyakan orang akan lebih memilih orang yang lebih tua dalam memimpin dari pada orang muda.

Ketidakpecayaan gereja terhadap kepemimpinan pemuda ini semakin nyata karena kehidupan pemuda Kristen itu sendiri. Selain karena kurang di anggap mampu, gereja enggan mempercayakan tanggung jawab yang besar kepada pemuda karena kehidupan pemuda Kristen yang sering kali dianggap jauh dari firman Tuhan. Pemuda memang memiliki semangat yang tinggi dan pemikiran yang brilian , akan tetapi gaya hidup Kristen juga merupakan syarat sebagai pemimpin Kristen. Perkembangan jaman dan pengaruh lingkunganlah yang sangat mempengaruhi sikap dan tindakan pemuda. Maka tak heran jika

\footnotetext{
${ }^{4}$ Santy Sahartian, "Pengaruh Pembinaan Rohani Gereja Berdasarkan Efesus 4:17-24 Terhadap Gaya Hidup Konsumerisme Pemuda Gereja Pantekosta Di Indonesia Theofilus Blitar," Jurnal Teologi Berita Hidup 1 (2018), https://e-journal.sttberitahidup.ac.id/index.php/jbh/article/view/3.
} 
pemuda sering kali jatuh dalam rupa-rupa dosa sehingga pemimpin muda tidak dipercayai. Maka dari itu penelitian ini akan membahas agar pemimpin muda gereja dapat melaksanakan tugas dengan baik dan dipercaya oleh jemaat. Penelitian ini membahas tiga bagian penting yaitu tugas pemimpin jemaat atau gembala menurut 1 Timotius 4, menemukan maksud dari pemimpin muda masa kini, dan menemukan bagaimana relevansi tugas pemimpin muda Kristen masa kini menurut 1 Timotius 4.

\section{METODE}

Penelitian ini mempergunakan pendekatan penelitian kualitatif dengan pendekatan studi literatur, melalui penelusuran teori-teori dan hasil penelitian yang berkaitan dengan tugas gembala jemaat dan kepemimpinan pemuda. Penelitian teologis dengan melakukan parsing dan eksegesis dengan bantuan BibleWokrs 7, Sabda, e-sword, jurnal, Kamus, Tafsiran; Bible commentary, eksposisi, study, devosi dan ensiklopedi. Penelitian dibidang sains menggunakan bantuan buku-buku dan jurnal-jurnal yang berkaitan.

\section{ANALISIS TUGAS GEMBALA JEMAAT MENURUT 1 TIMOTIUS 4:6-16}

Peneliti pada bagian ini akan menyampaikan apa sajakah yang menjadi tugas pemimpin jemaat dalam memimpin umat Tuhan menurut surat Paulus yang pertama kepada Timotius, secara khusus menurut 1 Timotius 4 :

\section{Mengingatkan (Ayat 6)}

Dalam ayat 6 Paulus menasihati Timotius untuk selalu mengingatkan saudarasaudara seiman tentang waspada akan penyesat-penyesat. "Mengingatkan" menggunakan

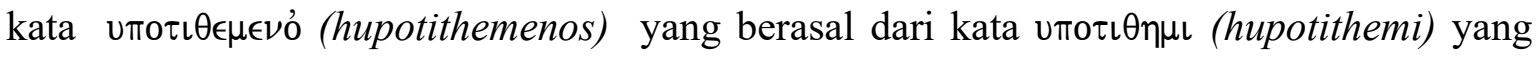
berarti mempertaruhkan,meletakkan dihadapan, menunjukkan, mengajar. Jadi upotiyemenov adalah "menunjukkan" atau "mengajar" 5

Paulus menasihati Timotius untuk senantiasa mengingatkan jemaat supaya tidak terpengaruh dengan munculnya pengajar-pengajar sesat. Dengan melakukan hal tersebut ada dampak yang diperoleh Timotius. Peneliti menyimpulkan bahwa tugas gembala jemaat sebagai pemimpin dalam hal ini adalah selalu mengingatkan jemaat akan tantangan dunia ini yang bisa menyesatkan.

\footnotetext{
${ }^{5}$ Donald Guthrie, Tafsiran Alkitab Masa Kini, Volume 3 (Jakarta: Yayasan Komunikasi Bina Kasih, 1996).
} 


\section{Mengajarkan Kebenaran (ayat 7-11)}

Paulus juga mengajarkan kepada Timotius untuk memberitakan dan mengajarkan apa yang telah dia terima. Dalam ayat 11 tertulis "Beritakanlah dan ajarkanlah semuanya itu”. Kata "beritakanlah" digunakan kata paraggelle merupakan kata kerja aktif imperaktif kepada orang kedua tunggal. Jadi paraggelle yaitu "memerintah". Sedangkan "ajarkanlah" digunakan kata didasko merupakan kata kerja aktif imperaktif kepada orang kedua tunggal. Jadi didasko juga merupakan perintah kepada Timotius untuk mengajar. Tugas pemimpin jemaat dalam hal ini adalah untuk mengajar jemaat untuk mengerti firman Tuhan. ${ }^{6}$

Ada beberapa hal yang telah diajarkan Paulus kepada Timotius yang juga harus diberitakan dan diajarkan kepada jemaat Efesus untuk mewasdai ajaran sesat yang mengancam jemaat untuk murtad dari kebenaran.

\section{Menjauhi Takhayul}

Dalam ayat 7a dituliskan "Tetapi jauhilah takhayul dan dongeng nenek-nenek tua......" .Takhayul” berasal dari kata bebhlous (bebhlos) merupakan jenis kata adjectif yang memiliki arti "nafsu yang rendah", orang duniawi, tak suci, takhayul, yang tidak suci. Dalam NIV digunakan kata Myths yang artinya adalah "mitos".

Salah satu yang harus diajarkan oleh Gembala jemaat sebagai pemimpin adalah menjauhi takhayul atau hal-hal duniawi seperti yang Paulus kehendaki pada Timotius sebagai pemimpin jemaat Efesus untuk mengajarkan jemaat Efesus untuk menjauhi mitosmotos atau cerita-cerita dongeng yang tidak berguna.

\section{Melatih Diri Beribadah}

Dalam ayat 7 b dituliskan “...Latihlah dirimu beribadah.” Kata 'latihlah' bersal dari kata gumnaze yang berarti perintah untuk melatih. Sedangkan 'beribadah' dari kata eusebeia merupakan noun feminin yang artinya kesalehan; ibadah; perbuatan-perbuatan/hidup yang saleh, dalam KJV kata eusebeia (eusebeia) diterjemahkan 'godliness' yang berarti 'kesalehan'. Dalam ayat ini Paulus meminta kepada Timotius untuk melatih diri untuk hidup saleh. Demikian juga yang harus diajarkan Timotius kepada jemaat.

Dalam ayat 8 juga dijelaskan bahwa latihan badani itu terbatas kegunaannya sedangkan melatih beribadah atau kesalehan mengandung janji. Kata 'karena mengandung janji’ dalam bahasa Yunani $\epsilon \pi \alpha \gamma \gamma \in \lambda\llcorner\alpha \nu \in \chi 0 v \sigma \alpha$. Kata echousa merupakan kata kerja bentuk perfect yang artinya mempunyai, memperoleh, memegang, memakai, menjaga, 1962).

${ }^{6}$ Everett Harrison Charles Pfeiffer, ed., The Wycliffe Bible Commentary (Malang: Gandum Mas, 
mempertimbangkan. Sedangkan epaggelian merupakan noun feminime yang artinya janji atau keputusan. Jadi epaggelian echousa adalah telah memiliki janji. Janji yang dimaksudkan yaitu janji dalam hidup saat ini dan juga hidup yang akan datang.

\section{Menjadi Teladan (Ayat 12)}

Kata teladan dalam bahasa Yunani adalah tupov (tupos) merupakan noun masculine yang artinya adalah teladan, contoh, tanda, pola ${ }^{7}$. Ini salah satu syarat yang harus dimiliki untuk seorang pemimpin gereja. Ada beberapa hal yang harus diperhatikan dalam menjadi teladan bagi jemaat seperti yang disampaikan Paulus kepada Timotius.

\section{Keteladanan dalam Perkataan}

Perkataan dalam bahasa Yunani adalah logov yang dapat diartikan sesuatu yang dikatakan misalnya; perkataan, firman, ajaran. Paulus menasihati Timotius untuk menjadi teladan dalam perkataannya supaya dia tidak dianggap remeh oleh jemaat. Keteladanan dalam perkataan berarti penguasaan diri atas lidah dan kata yang dikeluarkan baik kepada pribadi atau kepada umum sebagai bentuk pengajaran di sekolah maupun di gereja ${ }^{8}$. Hamba Tuhan harus dapat menjaga rahasia, menghindari perkataan negatif, perkataan kotor, perkataan yang menyakitkan, menghindari fitnah dan gosip. Jadi pemimpin dituntut mampu menjadi teladan dalam perkataan yang baik, jujur, penuh hikmat, menguatkan dan membangun orang lain.

\section{Keteladanan dalam Tingkah laku}

Tingkah laku dalam bahasa Yunani adalah Anastrofe yang dapat diartikan cara hidup, perilaku. Paulus menghendaki Timotius dapat menjadi teladan dalam cara hidupnya.Tingkah laku adalah sesuatu yang dilakukan seseorang untuk mencapai satu maksud tertentu sesuai dengan apa yang dirasa dan dipikirkan. Perkataan tanpa teladan dalam tingkah laku akan menjadi hampa. Sebagaimana hati adalah sumber perkataan, maka hati juga sumber tingkah laku. Hati dan pikiran seseorang tergambar dalam perkataan dan tingkah lakunya. Tingkah laku yang dapat menjadi panutan murid dan orang yang kita layani adalah tingkah laku yang bermuara dari hati yang baik, yang dikuasai Tuhan ${ }^{9}$. Sebagai Pemimpin jemaat sudah semestinya Timotius memiliki tingkah laku atau cara hidup yang benar sehingga dapat menjadi teladan bagi jemaat.

\footnotetext{
${ }^{7}$ R. Budiman, Surat 1 \& 2 Timotius Dan Titus (Jakarta: BPK Gunung Mulia, 2016).41

${ }^{8}$ Erich Unarto, Bertumbuh Dalam Karakter Baru, 4th ed. (Jakarta: Pustaka Sorgawi, 2006). 128

${ }^{9}$ J. Wesley Brill, Tafsiran Surat Timotius \& Titus (Bandung: Kalam Hidup, 1978).122
} 


\section{Keteladanan dalam Kasih}

Kasih yang dimaksud adalah agape/ kasih yang sempurna, yaitu kasih Tuhan atau kehendak baik. Sebab kasih tak berkesudahan (1 Kort.13:8). Kasih ini dinyatakan kepada Tuhan dan sesama tanpa pamrih (gift-love). Bukan kasih yang terjadi karena suatu kepentingan/ egoisme. Allah mengasihi kita bukan sekedar teori, tetapi memberikan putra tunggal-Nya mati bagi mengganti hukuman kita agar kita selamat. Kasih Kristiani juga bukan sekedar emosional dan perasaan belaka, tetapi kasih dalam tindakan nyata. Kasih harus nampak dalam hidup dan pelayanan kita. Oleh karena itu, hanya manusia yang berserah pada Allah yang dapat mewujudkan keteladanan kasih tanpa pamrih ini . Sudah selayaknya seorang gembala jemaat harus memiliki kasih seperti yang diajarkan Paulus kepada Timotius.

\section{Keteladanan dalam Kesetiaan}

Teks dalam bahasa Yunani memakai kata En Pistei = iman, kepercayaan, keyakinan, yang berarti juga kesetiaan. Kata 'kesetiaan' bila diterapkan kepada Allah, maka kesetiaan menunjuk kepada sifat Allah yang dapat dipercaya secara mutlak, keteguhan-Nya yang tetap pada semua apa yang pernah Ia janjikan terhadap sumpah-sumpah-Nya, kasih setia-Nya, serta sifat-Nya yang tidak berubah-ubah (bnd. Ulangan 7: 9). Bila kesetiaan diterapkan pada manusia, maka kesetiaan menunjuk kepada hal dapatnya seseorang menepati perkataannya dan memenuhi tanggung jawab (bnd. Mat. 25:20-21) ${ }^{10}$. Kesetiaan berkaitan erat dengan iman. Orang beriman pastilah orang yang setia kepada Tuhan. Kesetiaan dibuktikan dengan hidup bertanggung jawab.

\section{Keteladanan dalam Kesucian}

Kesucian menggunakan kata en agneia berarti ‘kemurnian' atau 'kesucian'. Hal yang harus ditunjukkan Timotius adalah kesucian dalam hal moral yang mengarah pada kemurnian tubuh dan pikiran.

Perlu pengendalian diri terhadap godaan dosa, mampu mengawasi dirinya sendiri, menjaga diri dari dosa seks, korupsi, pengajaran dan pelayanannya harus bertujuan untuk menjaga dirinya agar dapat menjadi alat untuk menyelamatkan orang yang mendengarnya.

Gembala Jemaat sebagai pemimpin yang memiliki karakter demikian, tidak akan dianggap rendah dan bahkan menunjukkan kualitas kepemimpinan. Dan melalui keteladannanya akan melahirkan generasi para pemimpin yang berkarakter dan berkualitas.

${ }^{10}$ William Barclay, Pemahaman Alkitab Setiap Hari: 1 Dan 2 Timotius, Titus, Filemon (Jakarta: Gunung Mulia, 2011).155 


\section{Bertumbuh dalam Pelayanan (ayat 13-15)}

Paulus juga menasihati Timotius untuk kemajuan dirinya dapat dilihat oleh semua orang. Artinya bahwa Timotius harus mengalami pertumbuhan rohani. Dalam ayat 15 Paulus mengatakan “....supaya kemajuanmu nyata kepada semua orang.” Kata 'kemajuan’ berasal dari kata прокопп yang berarti kemajuan. Sedangkan kata 'nyata' berasal dari kata fanera yang berarti diketahui, jelas, nyata, tampak. Paulus berharap bahwa semua orang dapat mengetahui kemajuan dari Timotius sebagai pemimpin jemaat.

Untuk memajukan diri Timotius harus melakukan beberapa hal sesuai apa yang dikatakan Paulus dalam ayat sebelumnya.

\section{Tekun Mengajar}

Untuk memajukan diri ada hal yang harus dilakukan Timotius sebagai pemimpin jemaat adalah tekun (ayat 13). Tekun berasal dari bahasa Yunani $\pi \rho \sigma \sigma \epsilon \chi \omega$ yang artinya aadalah memperhatikan dengan baik-baik. Pertama, membaca kitab-kitab suci. Namun jelas bahwa yang dibacakan dalam ibadah jemaat itu kitab-kitab Perjanjian Lama dan juga suratsurat Paulus yang sudah beredar. Kedua, membangun jemaat. Kata 'membangun' menggunakan kata $\pi \alpha \rho \alpha \kappa \lambda \eta \sigma \in \iota$ yang berarti mendorong. Ketiga, mengajar jemaat.

Jadi yang menjadi syarat untuk memajukan diri atau bertumbuh dalam hal ini adalah Timotius sebagai pemimpin jemaat harus tekun atau menaruh perhatian pada pembacaan kitab suci, mendorong dan mengajar jemaat.

\section{Tidak Lalai Mempergunakan Karunia}

Selain tekun untuk memajukan diri, Paulus juga menasihati Timotius untuk tidak lalai dalam mempergunakan karunia. Dalam ayat 14 Paulus mengatakan, Kata lalai dalam bahasa Yunani adalah amaleo (ameleo) yang berarti mengabaikan. Paulus tidak mau Timotius mengabaikan karunia yang telah dia miliki dalam pelayanan. Karena di dalam pelayanan peran karunia sangatlah penting.

Dengan mengingatkan Timotius akan karunia yang telah ia terima ini, Timotius dikuatkan kembali imannya.ia mampu melakukan tugasnya yang berat, karena ia telah menerima kekuatan dari Roh Kudus untuk itu. Tetapi ia juga bertanggung jawab untuk mempergunakan karunia itu, artinya ia harus mengembangkannya

Dalam hal ini peneliti menyimpulkan bahwa Gembala Jemaat sebagai pemimpin haruslah memajukan diri untuk kesuksesan pelayanan dengan cara tekun dalam mempelajari alkitab, membangun jemaat dan mengajar jemaat. Di samping tekun untuk memajukan diri 
serorag pemimpin jemaat harus mempergunakan karunia yang telah ia terima karena itu merupakan kekuatan yang Roh Kudus berikan untuk pekerjaan Tuhan.

\section{Mengawasi diri dan ajaran (Ayat 16)}

Tugas yang harus dilakukan Timotius pada ayat 16 yaitu Timotius harus mengawasi diri dan mengawasi ajarannya itu. Kata 'awasilah' dalam ayat 16 ini berasal dari kata $\epsilon \pi \epsilon \chi \omega$ (epecho) yang artinya adalah 'menatap' atau 'menaruh perhatian'. Sedangkan kata 'dirimu sendiri' dalam NIV menggunakan kata your life yang artinya hidupmu. Kemudian kata ajaranmu berasal dari kata $\delta\llcorner\delta \alpha \sigma \kappa \alpha \lambda \iota \alpha$ (didaskalia) yang artinya pengajaran atau perintah. Jadi kalimat "awasilah dirimu sendiri dan awasilah ajaranmu" yang dikatakan Paulus kepada Timotius adalah perintah untuk menaruh perhatian terhadap hidup secara pribadi Tomotius dan apa yang menjadi pengajarannya supaya tetap berada dalam kebenaran.

Gembala jemaat sebagai pemimpin juga bertugas untuk selalu mengawasi dirinya sendiri dan pengajaranya supaya tetap berada dalam jalur yang benar, tidak menyimpang dari firman Tuhan. Karena jika pemimpin jemaat melakukan hal itu akan ada yang dihasilkan ${ }^{11}$. Sebagai pemimpin Timotius harus senantiasa mengawasi kehidupannya sendiri dan juga apa yang dia ajarkan kepada jemaat. Hal itu akan berdampak positif bagi diri sendiri maupun kepada jemaat. Kata 'menyelamatkan' berasal dari kata $\sigma \omega \zeta \omega$ (sozo) yang artinya menyelamatkan, menolong, membebaskan, menyembuhkan. Yang dimaksudkan di sini adalah 'menolong' Timotius dan Jemaat tetap berada dalam kebenaran sehingga tidak terpengaruh oleh pengajaran sesat yang ada ${ }^{12}$.

Sudah menjadi tugas seorang Gembala jemaat untuk selalu mengawasi hidupnya sendiri dan juga apa yang dia ajarkan, supaya tidak jatuh kedalam dosa ataupun tersesat.

\section{PEMIMPIN MUDA KRISTEN MASA KINI}

Pemimpin muda Kristen adalah seorang yang menjalankan tugas kepemimpinan Kristen dalam usia yang relatif muda. Pemimpin muda masa kini sendiri mengalami kontroversi, sebagian orang berpendapat bahwa pemimpin muda belum mampu karena minimnya pengalaman sedangkan sebagian orang juga berpendapat bahwa pemimpin usia muda lebih memiliki kreativitas dalam memimpin ${ }^{13}$.

\footnotetext{
${ }^{11}$ John C Maxwell, Mengembangkan Kepemimpinan Di Dalam Diri Anda (Jakarta: Binarupa Aksara, 1995).45

${ }^{12}$ Santy Sahartian, "Pengaruh Pembinaan Rohani Keluarga Terhadap Karakter Pemuda Berdasarkan Kolose 2: 6-10," Fidei: Jurnal Teologi Sistematika dan Pratika 2 (2019): 20-39, http://www.stttawangmangu.ac.id/e-journal/index.php/fidei/article/view/30.

${ }^{13}$ Gatot Iswantoro, Kepemimpinan Dengan Hati Nurani (Jakarta: Tugu Publisher, 2013).17-18
} 
Dalam bagian ini peneliti mencoba memaparkan apa kekurangan dan kelebihan pemimpin muda yang ada saat ini berdasarkan beberapa sumber dan wawancara yang dilakukan oleh peneliti.

John C. Maxwell di dalam bukunya mengatakan;

"Dalam berbagai pertemuan akhir pekan saya dengan ribuan orang muda di seluruh Amerika Serikat, saya selalu melihat dampak dari generasi yang hidup di bawah pengaruh rock ' $\mathrm{n}$ roll, tekanan sesama remaja, dan orang- orang yang tidak memiliki fondasi kukuh di dalam Allah. Hasilnya generasi muda yang sakit, remuk, bimbang, dan pada akhirnya saling menyakiti sesamanya." 14

Dengan pernyataan John C. Maxwell tersebut peneliti dapat menyimpulkan bahwa banyak pemuda yang terbawa arus dunia dan tidak mempunyai iman yang kuat sebagai fondasi mereka. Sehingga pemuda cenderung tidak mengerti apa tujuan hidupnya dan cenderung hanya memikirkan kesenangannya sendiri tanpa memikirkan orang lain.

Memang banyak hal yang dilakukan oleh pemuda yang tidak sesuai dengan kebenaran firman Tuhan. Berbagai macam kenakalan remaja sering kali terjadi seiring perkembangan zaman. Tidak sedikit pula pemuda Kristen terlibat di dalamnya. Itu semua karena kecenderungan pemuda yang menginginkan kesenangan pribadi tanpa memikirkan dampaknya terhadap orang lain bahkan dampak terhadap dirinya sendiri.

Dalam bagaian ini akan di bahas menegenai apa yang menjadi kelebihan seorang pemimpin muda dalam proses kepemimpinanannya:

1. Lebih antusias dan bersemangat

2. Terlalu cepat dalam mengambil keputusan, atau berani "Gambling"

3. Bertanggung jawab

4. Potensi- potensi Generasi Muda

Potensi-potensi yang terdapat pada generasi muda perlu dikembangkan adalah:

1. Idealisme dan daya kritis

2. Dinamika dan kreativitas

3. Keberanian Mengambil Risiko

4. Opimis dan kegairahan semangat

5. Sifat kemandirian, disiplin, peduli, dan bertanggung jawab

6. Keanekaragaman dalam persatuan dan kesatuan

7. Patriotisme dan Nasionalisme

8. Kemampuan menguasai ilmu dan teknologi

\footnotetext{
${ }^{14}$ John C Maxwell, Semua Orang Bisa Memimpin (Jakarta: Gunung Mulia, 2013).7
} 
Beberapa ciri positif yang dimiliki kaum muda ini tidak dimiliki oleh kepemimpinan kaum tua, dimana ketika kedua golongan leadership ini dikonvergensikan, akan menciptakan kepemimpinan yang lebih solid ketimbang kepemimpinan yang didominasi oleh kaum tua saja, seperti yang terjadi di negara kita sekarang. Jadi menurut hemat saya, sangatlah pantas apabila kaum muda diberi kesempatan untuk mengemukakan apresiasinya dan atau memberikan gaya yang berbeda dalam memimpin.

Pemimpin muda patut mendapatkan kesempatan dalam memimpin dengan kelebihan yang telah dimiliki pemuda secara umum. Narasumber Agung Habsoro,S.Pd mengatakan dalam sebuah wawancara, "seorang pemimpin muda biasanya lebih inovatif." sedangkan seorang kepala sekolah bernama Lidya, S.Pd mengatakan "pemimpin muda mendapat keuntungan dalam hal penerapan ilmu yang baru saja dia dapatkan”

Kesimpulan yang diambil peneliti, pemimpin muda lebih kreatif dan inovatif dibandingkan dengan pemimpin yang lebih tua karena pemuda cenderung menerapkan secara langsung ilmu yang baru didapatkan.

Berlawanan dengan pendapat di atas peneliti juga menyampaikan beberapa pendapat negatif tentang pemimpin muda sebagai hasil wawancara. Seorang pengusaha rumahan dan juga seorang pendidik bernama Sri Saryanti mengatakan dalam sebuah wawancara, "Pemimpin muda masih kurang dalam hal pengalaman meskipun memiliki semangat." Seorang sarjana ekonomi dan seorang pendidik bernama Rahayu Katri Andajani, SE mengatakan, "Seorang pemimpin muda masih sangat emosional". Seorang sarjana hukum sekaligus seorang pendidik bernama Ratna Ratih Tri Handayani, SH mengatakan, "Pemimpin muda sering bertindak tanpa berpikir panjang" Kemudian seorang guru bernama Wijiyanti, S.Pd juga mengatakan, "Pemimpin muda sulit menerima masukan dari orang lain"

Dari beberapa pendapat di atas peneliti menyimpulkan bahwa pemimpin usia muda masa kini memiliki banyak sekali kelemahan sehingga pemimpin muda kurang diterima dan dihargai oleh orang banyak.

\section{TUGAS PEMIMPIN MUDA KRISTEN MASA KINI SEBAGAI GEMBALA MENURUT 1 TIMOTIUS 4}

Dalam bagian ini peneliti menemukan relevansi antara tugas gembala menurut 1 Timotius 4 dengan pemimpin muda Kristen masa kini. 


\section{Mengingatkan Jemaat akan Firman}

Ingatan adalah sesuatu yang pernah diketahui dan tersimpan dalam otak manusia kemudian dapat dimunculkan kembali.Seorang pemimpin usia muda memiliki tugas untuk mengingatkan orang sedang dipimpin tentang tujuan awal, prinsip-prinsip kebenaran, dan norma-norma awal. Ini artinya memunculkan kenbali apa yang pernah tersimpan dalam pikiran seseorang.

Menurut nasihat Paulus kepada Timotius dalam surat 1 Timotius 4:6 "Dengan selalu mengingatkan hal-hal itu kepada saudara-saudara kita, engkau akan menjadi seorang pelayan Kristus Yesus yang baik, terdidik dalam soal-soal pokok iman kita dan dalam ajaran sehat yang telah kauikuti selama ini.'Timotius disarankan untuk selalu mengingatkan jemaat tentang ajaran yang benar dan munculnya ajaran sesat.

Jadi peneliti menyimpulkan bahwa seorang pemimpin, dalam hal ini adalah pemimpin muda Kristen harus senantiasa mengingatkan orang yang mereka pimpin. Yaitu memunculkan kembali kebenaran Firman Tuhan yang pernah disimpan dalam pikiran jika mereka hidup melupakan Firman Tuhan.

\section{Mengajarkan Kebenaran Firman}

Tugas pemimpin muda Kristen yang selanjutnya adalah mengajarkan kebenaran. Sebelum mengetahui bagaimana seorang pemimpin muda Kristen mengajarkan kebenaran perlu diketahui juga apa itu mengajar dan apa itu kebenaran ${ }^{15}$.

Kebenaran mengandung dua makna yaitu kebenaran merupakan sesuatu yang akurat sesuai fakta dan kebenaran merupakan lawan kata dari kesalahan. Alkitab sebagai firman Tuhan telah memenuhi kedua hal tersebut. Di dalam konteks 1 Timotius 4: 7-11 yang berbunyi “(7)Tetapi jauhilah takhayul dan dongeng nenek-nenek tua. Latihlah dirimu beribadah. (8)Latihan badani terbatas gunanya, tetapi ibadah itu berguna dalam segala hal, karena mengandung janji, baik untuk hidup ini maupun untuk hidup yang akan datang. (9) Perkataan ini benar dan patut diterima sepenuhnya. (') Itulah sebabnya kita berjerih payah dan berjuang, karena kita menaruh pengharapan kita kepada Allah yang hidup, Juruselamat semua manusia, terutama mereka yang percaya. (11) Beritakanlah dan ajarkanlah semuanya itu." Kebenaran yang dimaksud oleh Paulus adalah semua yang telah diajarkan Paulus kepada Timotius.

${ }^{15}$ Henry $;$ Richard Blackaby, Kepemimpinan Rohani $=($ Spiritual Leadership $):$ Menggerakkan Umat Untuk Bergerak Berdasarkan Agenda Allah, ed. Thomas Heru and Lyndon Saputra (Batam: Gospell Press, 2005). 
Jadi penulis menyimpulkan bahwa seorang pemimpin muda Kristen juga bertugas mengajarkan kebenaran. Maksudnya ialah menyampaikan apa yang benar menurut firman Tuhan sehingga orang yang dipimpinnya dapat mengerti kebenaran menurut Alkitab kemudian melakukannya.

\section{Menjadi Teladan}

Dalam bagain ini penulis juga menjelaskan tugas pemimpin muda Kristen yang selanjutnya, yaitu seorang pemimpin muda Kristen harus menjadi teladan. Sebelum lebih lanjut dibahas tentang pemimpin usia muda yang menjadi teladan, akan disampaikan tentang apa yang dimaksud keteladanan. Integritas bukan apa yang kita lakukan, tetapi siapa kita sesungguhnya. Pemimpin Kristen harus juga memiliki integritas untuk memimpin sebuah organisasi yang dipimpinnya ${ }^{16}$.

Jadi Keteladanan adalah perbuatan dan kelakuan orang tersebut layak dan baik untuk dicontoh. Artinya seseorang yang menjadi figur adalah bentuk, wujud, dan tokoh merupakan sentral yang menjadi pusat perhatian.

Hal ini menjadi tugas berat sebagai pemimpin muda Kristen dan juga Gereja. Untuk membawa pemuda-pemuda yang tersesat dalam dunianya untuk menjadi generasi pemimpin Gereja yang memiliki fondasi yang kuat dalam Tuhan ${ }^{17}$.

Jadi dalam hal ini peneliti menyimpulkan bahwa perlu adanya keteladanan sebagai seorang pemimpin khususnya pemimpin muda Kristen supaya dapat dihargai atau tidak dianggap remeh.

\section{Bertumbuh dalam Pelayanan}

Tugas pemimpin muda Kristen yang selanjutnya adalah bertumbuh. Seorang pemimpin memang sudah senantiasa memajukan dirinya sehingga orang dapat melihat bahwa pemimpinnya mengalami perkembangan seiring berjalannya waktu. Dalam hal ini peneliti menyimpulkan bahwa bertumbuh juga dapat diartikan dengan istilah proses pengembangan diri. Pengembangan diri adalah kegiatan atau usaha untuk meningkatkan kemampuan yang dimiliki.

Tentu seorang pemimpin usia muda dalam gereja perlu mengembangkan dirinya sebelum mengembangkan orang lain kearah yang lebih baik. Yang dimaksudkan disini adalah mengembangkan bakat atau potensi yang dia miliki sehingga mengalami

\footnotetext{
2008). 15

${ }^{16}$ Jonathan Lamb, Integritas: Memimpin Di Bawah Pengamatan Tuhan (Jakarta: Literatur Perkantas,

${ }^{17}$ John C Maxwell, 21 Hukum Kepemimpinan Sejati (Jakarta: Imannuel, 2008).120
} 
peningkatan ${ }^{18}$. Hal ini dapat terjadi apabila seorang pemimpin mempunyai ketekunan dan memperhatikan karunia yang ia miliki.

\section{Mengawasi Diri dan Pengajaran}

Dalam bagian ini peneliti akan menyampaikan tugas dari seorang pemimpin usia muda yang terakhir, yaitu senantiasa mengawasi diri dan juga mengawasi pengajarannya. Berikut akan dijelaskan apa yang dimaksud mengawasi diri dan pengajaran.

Di dalam konteks 1 Timotius 4:16 Paulus sedang menasihati Timotius agar dia selalu mengawasi diri dan pengajarannya supaya dia beserta orang yang diajar aman dari pengaruh ajaran sesat.

Mengawasi diri merupakan sebuah usaha untuk melihat dan menilai apa yang ada dalam diri sendiri sehingga dapat melihat setiap kekurangan dan kelebihan yang ada. Mengawasi diri juga bisa dikatakan sebagai intropeksi diri. Jika mengawasi diri merupakan sebuah tindakan melihat dan menilai diri sendiri, bagaimana dengan mengawasi pengajaran. Maka dari itu perlu diketahui terlebih dahulu, apa itu ajaran. Menurut Kamus Besar Bahasa Indonesia Ajaran adalah segala sesuatu yang diajarkan; nasihat; petuah; petunjuk.

Jadi sebagai pemimpin muda Kristen perlu untuk melihat dan menilai kekurangan atau kelebihan yang ada dalam dirinya dan juga ajarannya, supaya tetap teguh dalam kebenaran Firman Tuhan. Dalam konteks Timotius, Paulus ingin Timotius selalu mengawasi diri dan ajaran supaya selamat dari pengaruh ajaran sesat. Dengan kata lain Timotius harus selalu waspada terhadap ajaran sesat yang ada. Demikian pemimpin muda Kristen harus selalu waspada terhadap apapun.

\section{KESIMPULAN}

Tugas gembala jemaat sebagai pemimpin menurut 1 Timotius 4 adalah mengingatkan jemaat akan firman, mengajarkan kebenaran firman, menjadi teladan, bertumbuh dalam pelayanan, mengawasi diri dan ajaran.Pemimpin muda Kristen masa kini adalah seorang yang menjalankan tugas kepemimpinan Kristen dalam usia yang relatif muda. Pemimpin muda masa kini memiliki banyak sekali kelemahan sehingga pemimpin muda kurang diterima dan dihargai oleh orang banyak. Untuk mengatasi masalah tersebut maka pemimpin muda Kristen harus menerapkan tugas sebagai gembala jemaat menurut 1 Timotius 4 yaitu a) pemimpin muda Kristen perlu memberikan keteladanan sebagai seorang pemimpin supaya dapat dihargai atau tidak dianggap remeh, b) menyampaikan apa yang benar menurut

\footnotetext{
${ }^{18}$ Sen Sendjaya, Kepemimpinan Kristen (Yogyakarta: Kairos, 2004).229
} 
firman Tuhan bukan kecerdasan intelektual atau egoisme sehingga orang yang dipimpinnya dapat mengerti kebenaran menurut Alkitab kemudian melakukannya mengingatkan jemaat akan firman, c) pemimpin muda di gereja perlu mengembangkan dirinya sebelum mengembangkan orang lain kearah yang lebih baik mempunyai ketekunan dan memperhatikan karunia yang ia miliki, d) Pemimpin muda Kristen perlu melihat dan menilai kekurangan atau kelebihan yang ada dalam dirinya dan juga ajarannya, supaya tetap teguh dalam kebenaran Firman Tuhan, selalu mengawasi diri dan ajaran supaya selamat dari pengaruh ajaran sesat.

\section{REFERENSI}

Barclay, William. Pemahaman Alkitab Setiap Hari: 1 Dan 2 Timotius, Titus, Filemon. Jakarta: Gunung Mulia, 2011.

Charles Pfeiffer, Everett Harrison, ed. The Wycliffe Bible Commentary. Malang: Gandum Mas, 1962.

Donald Guthrie. Tafsiran Alkitab Masa Kini, Volume 3. Jakarta: Yayasan Komunikasi Bina Kasih, 1996.

Henry ; Richard Blackaby. Kepemimpinan Rohani $=($ Spiritual Leadership $):$ Menggerakkan Umat Untuk Bergerak Berdasarkan Agenda Allah. Edited by Thomas Heru and Lyndon Saputra. Batam: Gospell Press, 2005.

Iswantoro, Gatot. Kepemimpinan Dengan Hati Nurani. Jakarta: Tugu Publisher, 2013.

J. Wesley Brill. Tafsiran Surat Timotius \& Titus. Bandung: Kalam Hidup, 1978.

Jonathan Lamb. Integritas: Memimpin Di Bawah Pengamatan Tuhan. Jakarta: Literatur Perkantas, 2008.

Larry S. Julian. GOD Is My CEO. Jakarta: BIP, 2004.

Maxwell, John C. 21 Hukum Kepemimpinan Sejati. Jakarta: Imannuel, 2008.

-. Mengembangkan Kepemimpinan Di Dalam Diri Anda. Jakarta: Binarupa Aksara, 1995.

- Semua Orang Bisa Memimpin. Jakarta: Gunung Mulia, 2013.

R. Budiman. Surat 1 \& 2 Timotius Dan Titus. Jakarta: BPK Gunung Mulia, 2016.

Santy Sahartian. "Pengaruh Pembinaan Rohani Gereja Berdasarkan Efesus 4:17-24 Terhadap Gaya Hidup Konsumerisme Pemuda Gereja Pantekosta Di Indonesia Theofilus Blitar." Jurnal Teologi Berita Hidup 1 (2018). https://ejournal.sttberitahidup.ac.id/index.php/jbh/article/view/3.

_. "Pengaruh Pembinaan Rohani Keluarga Terhadap Karakter Pemuda Berdasarkan Kolose 2: 6-10." Fidei: Jurnal Teologi Sistematika dan Pratika 2 (2019): 20-39. http://www.stt-tawangmangu.ac.id/e-journal/index.php/fidei/article/view/30.

Sendjaya, Sen. Kepemimpinan Kristen. Yogyakarta: Kairos, 2004.

Unarto, Erich. Bertumbuh Dalam Karakter Baru. 4th ed. Jakarta: Pustaka Sorgawi, 2006. 